\title{
The problems of developing a tourist village
}

\author{
M.I. Alawi*, M.M. Habibi \& N.W. Rochmadi \\ Universitas Negeri Malang, Malang, Indonesia \\ B.S. Wiwoho \\ University of Queensland, Brisbane, Australia
}

\begin{abstract}
This study aimed to explain the role of village government in tourism development and identifying the inhibiting factors in the development of the Sendang Bulus Beji Pager Tourism and solutions to these obstacles. This research used a qualitative approach with a descriptive research type. The data collection techniques used were in-depth interviews, observation, and documentation. The results showed that the role of the village government in tourism development was to initiate the development of the Sendang Bulus Beji Pager Tourism. As the supervisor and person in charge of the development of the Sendang Bulus Beji Pager Tour and set the Sendang Bulus Beji Pager Tourism to be a Village-Owned Enterprise. The inhibiting factors for tourism development are limited funds, the absence of good tourism administration management. An effort to overcome the existing obstacles is that the Pager Village Government submits a request for assistance to the central government in the form of channeling funds and optimizing the use of village funds provided for tourism development and the updating of tourist rides and facilities.
\end{abstract}

Keywords: village government, Sendang Bulus, tourism

\section{INTRODUCTION}

Tourism has an important role in the economic development of a region. The economy of an area can increases if tourism in the area develops because many tourists come. Tourism activities can encourage and accelerate economic growth. In line with this, the impact of tourism on the socioeconomic conditions of local communities is grouped by Cohen (in Pitana \& Diarta, 2009) into eight major groups, namely: (1) impact on foreign exchange earnings, (2) impact on community income, (3) impact on employment, (4) impact on prices, (5) impact on distribution of society or profits, (6) impact on ownership and control, (7) impact on development in general and (8) impact on government revenues.

Regions in Indonesia have many potential tourist destinations that are scattered throughout the archipelago. Ponorogo Regency is a district located in East Java Province which has high potential resources that can be empowered by its tourism sector. There are several tourism potentials in Ponorogo Regency, including nature tourism, religious tourism and cultural tourism. Quoted from (Tempatwisataseru.com) in Ponorogo Regency, there are around 46 tourist destinations ranging from historical tourist attractions, natural attractions, museums, and water games that can be relied on for development.

Pager village is a village located at the eastern end of Bungkal District, 30 kilometers from downtown Ponorogo. There is a natural tourist attraction which is the only one in Ponorogo Regency and not found in other districts, namely Sendang Bulus. Sendang which means pond and bulus means softshell turtle. Since a long time ago, this spring has been known as the original habitat for

${ }^{*}$ Corresponding Author 
bulus. This spring has become an attractive tourist area because it offers a beautiful and unspoiled panorama, but because of the large amount of hunting and turmoil that has occured near the spring, this natural tourism has been neglected for years and has been deserted by visitors. So far, this spring is only used as a reservoir for irrigation for village farmers who own rice fields near the Sendang Bulus Beji Pager Tour. In 2015 this place began to be developed again until now it has become one of the famous tourist locations in Ponorogo Regency.

Sendang Bulus Beji Pager Tourism has several tourism potentials. The most important thing for the tourism potential is the existence of a spring or spring whose water is always available. The abundant water is usually used to irrigate rice fields. The next tourism potential is that this place is still very natural, the trees are also still shady plus the south and west of Sendang there are expanses of rice fields and mountains. Furthermore, there is the maintenance of freshwater fish, including tawes, tilapia, tombro fish and snakehead fish and fleas. Visitors can also feed directly to the fish that are kept there. The manager has provided feed in the form of pellets which are priced at 2000 per pack. In addition, visitors can also enjoy the view by riding a duck boat.

The role of the Pager Village government and all components in the community is very necessary, considering the potential in Sendang Bulus Beji Pager is very good to be developed. The development of a tourist attraction requires involved stakeholders, human resources, programs, funds and facilities. Based on the explanation above, the researcher is interested in researching "The Problems of Developing a Tourist Village." The researchers' reason is interested in taking the title is to find out what the role of the village government is in the development of tourism, where previously the tourist spot was not maintained and not managed until now it is developed and better managed so that now Sendang Bulus Beji Pager is a famous tourist destination in Ponorogo Regency.

\section{METHODS}

The location of this research is in Pager Village, Bungkal District, Ponorogo Regency. This study aims to explain the role of village government in tourism development. Identify the inhibiting factors in the development of the Sendang Bulus Beji Pager Tourism and seek solutions to these obstacles. This research uses a qualitative approach with descriptive research type. There are three sources of data in this study, namely humans, documents, and events. The data collection techniques used were in-depth interviews, observation and documentation. Researchers conducted interviews with several informants from Pager Village, researchers used observation to observe directly and record the conditions in the tourist environment of Sendang Bulus Beji Pager Village and Pager Village itself. The documents used in this study were documents obtained from informants regarding the role of the village government in developing the tourism development of Sendang Bulus Beji Pager in Pager Village, as well as photos during field observations and interviews with several informants. The data analysis technique used was the Miles and Huberman data analysis technique, namely data collection, data reduction, data presentation and conclusion drawing.

\section{RESULTS AND DISCUSSION}

Pager Village is located in Bungkal District, Ponorogo Regency, East Java Province, Indonesia. Pager Village consists of 3 hamlets, namely Bibis hamlet, Glagah Malang hamlet, and Pager Tengah hamlet, each of which is led by a head of the hamlet. In order to maximize the function of service to the community in Pager Village, the three hamlets are divided into 6 Rukun Warga (RW) and 18 Rukun Tetangga (RT). The pager village has an area of about $460 \mathrm{Ha}$ with a population of 1,847 people with 632 the number of heads of households. The role of village government in tourism development of Sendang Bulus Beji Pager.

Tourism has an important role in the economic development of a region. The economy of an area can increase if tourism in the area develops because of the many tourists who arrive. As 
one of the potential aspects in increasing regional and community income, tourism must be well developed. To develop a tourist object or place, it is necessary to have a role from the government and the community in its management. Tourism management must be carried out in a planned and comprehensive manner. So that optimal benefits can be obtained for the community, both from an economic, social and cultural perspective.

The Village Government of Pager is the party responsible for and is the supervisory party in the development of Sendang Bulus Beji Pager Tourism. The village government provides the opportunity for tourism conscious groups and the community to use these heritage springs to be maximally empowered so that the place can be even more useful for all villagers. One of the things that can be done to take advantage of the potential of this place is to build and develop the Sendang Bulus Beji Pager Tourism. According to Law Number 6 of 2014 Article 76 concerning Village spring ancestral heritage is included in the category of village assets. Then in article 77 paragraph 2 it is said that the management of village property is carried out to improve the welfare and standard of living of the village community and increase village income. In addition, the role played by the Pager Village government is in line with Law Number 6 of 2014 article 26 paragraph $2 \mathrm{c}$ which states that in carrying out its duties the Village Head has the authority as the holder of financial power and village assets. So, the village government in this case has the authority to grant permission to tourism conscious groups and community members to manage and utilize the assets of the Pager Village.

The development of Sendang Bulus Tourism can be categorized as village development. This is based on Law Number 6 of 2014 article 78 concerning Villages which states that village development aims to improve the welfare of rural communities and the quality of human life as well as poverty alleviation through meeting basic needs, building village facilities and infrastructure, developing local economic potential, and sustainable use of natural resources and the environment. The use of Sendang Bulus Beji Pager as a natural tourism has the potential to empower the community in a sustainable manner. This role was continued by including the Sendang Bulus Beji Pager Tourism into a village-owned enterprise called Sendang Wiro Prenggo through Village Regulation Number 04 of 2016 concerning the Establishment of Pager Village Owned Enterprises, Bungkal District, Ponorogo Regency on April 15, 2016. It is hoped that after its entry Sendang Bulus Beji Pager Tourism into a village-owned enterprise so that its development can be more planned and its development can be taken from village funds.

\subsection{Inhibiting factors in the development of Sendang Bulus Beji Pager tourism}

Tourism Development of Sendang Bulus Beji Pager is inseparable from constraints both from within and from outside. The main inhibiting factor for the development of the Sendang Bulus Beji Pager Tourism is the lack of funds for tourism development. Although the Sendang Bulus Beji Pager Tourism has entered a village-owned enterprise Sendang Tirto Prenggo belonging to Pager Village, in its development, it cannot be entirely taken from village funds. So that in the development of these tours requires a relatively long time and must be done gradually. The long and long process in developing this tourism makes visitors even more quiet, only on Saturdays and Sundays and only on holidays which are crowded with visitors considering that the Beji Pager Bulus Tourism is still under construction, making visitors who come uncertain. Suwantoro (2004) explains that one of the main elements that must be considered in supporting tourism development is one of the objects and tourist attractions. When the attractiveness of a tour weakens, the visitors who will come will also gradually decrease.

The next inhibiting factor is the lack of good tourism administration management. Filing that is not clear regarding the recapitulation of the number of visitors who come every day or about finances is still very simple. In addition, the Sendang Bulus Tourism, which is still under construction and has not been fully realized, as designed in the master plan is the reason for the temporary not being subject to tourist entry fees. What is feared by the manager if the tourism condition is still as it is now, the fee will result in a decrease in the number of visitors. This is still not in accordance with Law Number 6 of 2014 article 78 paragraph 2 concerning Villages that village development includes the 
planning, implementation and supervision stages. This article indicates that the development of a village must go through a planning stage that has a good time frame and structure. Even though all the plans for the development of the Sendang Bulus Beji Pager Tourism have been neatly arranged and have been documented in the form of a master plan, the administrative management of the tour is still not good.

\subsection{Efforts made to overcome obstacles in the development of the Sendang Bulus Beji Pager tourism}

The village government together with the management and the community must work together in overcoming the obstacles that become obstacles in the development of the Sendang Bulus Beji Pager Tourism. The most important obstacle is related to the lack of funds to develop this tourism. What the village government does is submit a request for financial assistance to the central government in the form of funds sharing. In addition, the village government has also submitted requests for assistance to the provincial government through the House of People's Representative aspiration program. Submission of requests for assistance to the central and provincial governments has been made even though they have not been received because all promises have not been realized. In addition, the village government must communicate frequently and often coordinate with all related parties and continue to establish relationships with the community to make investments or community investments.

To overcome obstacles related to village government funds and tourism managers, they try to optimize the use of village funds provided for tourism development. Development is carried out slowly and gradually every year so that the funds used can be optimized. The use of village funds in the process of developing the Sendang Bulus Beji Pager Tourism in accordance with Law Number 6 of 2014 article 74 paragraph 1 regarding Villages explains that village expenditure is prioritized to meet development needs agreed upon in village meetings and in accordance with the priorities of the regional/city government, government provincial and government areas.

The development process that continues in stages as planned in the master plan, especially the completion of the construction of the entrance gate for the Sendang Bulus Beji Pager Tourism, as well as the addition of new rides using village funds is expected to increase the number of visitors who come. This is in accordance with the opinion expressed by Yoeti (2008) that one of the things that can make a tourist object interesting is that there is something to do. Something to do in this case means that the location or tourist spot is not only visible but also can support tourists to do something. The addition of playgrounds, outbound, duck boats, odong-odong, providing fish feed at a price of 2000 per pack, and the presence of a swimming pool will make tourists feel more at home in the Sendang Bulus Beji Pager Tourism because there is something to be done, namely to surround the Sendang Bulus Beji Tourism. By riding a boat, children can also play in the playground, can ride odong-odong, eat fish as much as they want, and can also swim.

If visitors who come to tourist attractions are crowded, the stalls around the tour can get income from selling food and drinks. In addition, when the visitors who come are getting more crowded and the construction of the Sendang Bulus Beji Pager Tour is quickly completed and the tourist rides are also being added as planned, especially the gate entrance as the counter door, it will be able to immediately support improvements in the administration of visitor data collection and matters relating to data collection on the tourism development program.

\section{CONCLUSIONS}

The village government is one of the parties that plays an important role in tourism development. The role of the village government in the development of the first Sendang Bulus Beji Pager Tourism is as the initiator of the initial development of the Sendang Bulus Beji Pager Tourism. The second role is as a supervisor as well as participating as a person in charge of developing the Sendang Bulus Beji Pager Tourism. The third role is to provide permits and mobilize a tourism 
awareness group with the community to develop village assets that have not been maintained for a long time. The fifth role is to make tourism a village-owned enterprise. However, there are several inhibiting factors in the development of the Sendang Bulus Beji Pager Tourism. The first factor is limited funds for tourism development. The next factor is the lack of good tourism administration management. Efforts made to overcome obstacles in the development of the Sendang Bulus Beji Pager Tourism are the Pager Village Government applying for financial assistance to the central government in the form of fund distribution and optimization of the use of village funds provided for tourism development, vehicle renewal. and adding new facilities to ensure the Sendang Bulus Beji Pager Tourism.

\section{REFERENCES}

Akbar. H.U \& Purnomo, S. 2009. Metodologi penelitian sosial. Jakarta: Bumi Aksara.

Antariksa, B. 2016. Kebijakan pembangunan kepariwisataan (Pengembangan kepariwisataan yang berkelanjutan dan perlindungan kekayaan intelektual). Malang: Intrans Publishing.

Arikunto, S. 1996. Prosedur penelitian suatu pendekatan praktek. Jakarta: PT. Rineka Cipta.

Djafar, S. 2015. Evaluasi kebijakan pariwisata. Yogyakarta: Penerbit Ombak.

Martaleni. 2017. Pemasaran pariwisata di Indonesia. Malang: International Research and Development for Human Beings.

Maryani, E. 1991. Pengantar geografi pariwisata. Bandung: Jurusan Pendidikan Geografi IKIP Bandung.

Moleong, L.J. 2007. Metode penelitian kualitatif. Bandung: Remaja Rosdakarya Offset.

Moleong, L.J. 2014. Metode penelitian kualitatif edisi revisi. Bandung: Remaja Rosdakarya.

Pitana, I.G. \& Diarta, I. K. S. 2009. Pengantar ilmu pariwisata. Yogyakarta: Penerbit Andi.

Priasukmana, S. \& Mulyadin, M. 2001. Pembangunan desa wisata: Pelaksanaan Undang-Undang otonomi daerah.Jurnal: Info Sosial Ekonomi 2(1): 37-44.

Soedarmayanti. 2014. Membangun \& mengembangkan kebudayaan \& industri pariwisata (Bunga rampai tulisan pariwisata). Bandung: Refika Aditama.

Sugiyono. 2016. Metode penelitian pendidikan pendekatan kuantitatif, kualitatif dan R\&D. Bandung: Alfabeta.

Sujali. 1989. Geografi pariwisata dan kepariwisataan. Yogyakarta: Fakultas Geografi Universitas Gadjah Mada

Sukmadinata. 2013. Metode penelitian pendidikan. Bandung: Remaja Rosdakarya

Sukriono, D. 2010. Pembaharuan hukum pemerintahan desa. Malang: Setara Press.

Suwantoro, G. 2004. Dasar-dasar pariwisata. Yogyakarta: Penerbit Andi.

Republik of Indonesia. 2009. Undang-Undang Nomor 10 Tahun 2009 tentang Kepariwisataan.

Republik of Indonesia. 2014. Undang-Undang Nomor 6 Tahun 2014 tentang Desa.

Wardiyanata. 2006. Metode penelitian pariwisata. Jogjakarta: Penerbit Andi.

Yoeti, A.O. 2002. Perencanaan dan pengembangan pariwisata. Jakarta: Cetakan Pertama Pradnya Paramita.

Yoeti, A.O. 2008. Ekonomi pariwisata: introduksi informasi dan implementasi. Jakarta: Kompas. 